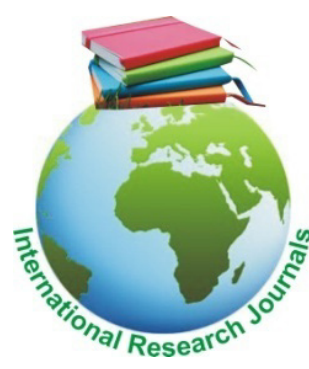

Journal of Research in Environmental Science and Toxicology Vol. 7(2) pp. 47-52, Dec, 2018

DOI: http:/dx.doi.org/10.14303/jrest.2018.020

Available online http://www.interesjournals.org/JREST

Copyright (c2018 International Research Journals

Full Length Research Paper

\title{
Review on hospital wastewater as a source of emerging drug resistance pathogens
}

\author{
Tsegahun Asfaw \\ Department of Medical Laboratory Science, Debre Berhan University, Debre Berhan, \\ tsegahun.asfaw12@gmail.com
}

\begin{abstract}
Large concentration of antibiotics is excreted through faces and urine of patient and reaches liquid wastes and act as selective pressure on hospital microflora and development of antibiotic resistant pathogens. Therefore, this seminar review paper aims to exploit the contribution of wastewater as a source of drug resistance pathogens. The literature was searched by different electronic databases like Google Scholar and PubMed and then reviewed systematically get valuable conculusion from recent article. This review may help to appraise hospital wastewater manegment system in Ethiopia.
\end{abstract}

Keywords: Drug resistance, pathogens, hospital, wastewater.

\section{INTRODUCTION}

Wastewater is used water of the community. It is an ideal media for microorganisms and carries the resistant gene into the sewage system [1-3]. Large amount of antibiotics are daily used for patient care and control of infection in hospitals. Large concentration of these antibiotics is excreted through faces and urine of patient and reaches liquid wastes. Therefore, wastewater from hospitals contains resistant gene and antibiotic residues that inhibit the growth of susceptible microorganism through selection pressure [4,5]. Resistant bacteria in the environment carry transmissible gene, by acting as a vector or reservoir of resistant gene [6-9]. There are also the most dangerous micro-organism contaminants for human health, and wastewaters are one of the most serious pollutants discharging to the environment $[9,10]$. The multidrug resistance pattern seen in microbial isolates from hospital wastewater include most of the antibiotics used presently. Therfore the problem is the transfer of this resistance to pathogenic microorganism to lead currently available antibiotics to be vain [11]. Improper antibiotic usage, ineffective infection control program and lack of better management of hospital wastewater is the main factor for dissemination of antimicrobial resistance gene in the environment in developing countries like Ethiopia. To limit its public health impact, critical evaluation, treatment and periodic assessment of hospital wastewater released to receiving environment is mandatory. Therefore this review paper aimed to exploit the roll of hospital wastewater as source of emerging drug resistance pathogens in the environment.

\section{MATERIALS AND METHODS}

The literatures were searched in different electronic data base like Pub Med, Google scholars and research gate based on the key terms like hospital wastewater and drug resistance pathogens in the environment. Studies published on different reputable journals and emphasizing for objective of this study were reviewed and sumerized systematically. Articles written in English language, published recently and having full length forms were included.

\section{DISSCUSION}

\section{Hospital Wastewater}

Hospitals are an essential asset of population and waste production is usual outcome from its service delivery. Hospital wastewater contains harmful pollutant and generated from all activities of the hospital as medical and non medical activities [12]. Disinfectants and drug components like active substances, formulation adjuvant, pigments, dyes and used drugs are excreteed by the patients and get into wastewater after use. The different 
substances, which are not biodegradable, may finally enter surface water from wastewater treatment plant effluents and enter groundwater after the application of sewage sludge as fertilizers [13]. If hospital wastewater not managed properly, disposal of infectious wastes and equipment decrease the quality of water [14].

\section{Treatment Methods for Hospital Wastewater}

Formerly, the objective of wastewater treatment was about environmental issue. Then after, reduction of Biological Oxygens Demand (BOD), pathogenic microorganism and suspended solids got attentions. At present the strategies is changed to reduce multidrug resistant pathogens $[15,16]$. There are different methods of wastewater treatment like activated sludge treatment and oxidation ditch, membrane bioreactor, convectional activated sludge, integrated anaerobic-aerobic fixedfilm reactor and wastewater stabilization pond. Those methods are different in removal efficiency of pathogens. For example, activated sludge treatment and oxidation ditch are less effective in eliminating bacteria and parasites from hospital effluent. Study conducted in Thailand showed microbial contamination of treated wastewater is exceeded standard levels of total coliforms and fecal coliforms were found in $5.6 \%$ and $20.8 \%$ of samples in $8.3 \%$ and $41.7 \%$ of hospitals, respectively. Pathogenic bacteria: Vibrio and Salmonella spp. were found in $3.1 \%$ of samples and in $12.5 \%$ of hospitals [17]. However, Membrane Bioreactor (MBR) may play a key role in hospital wastewater treatment because of the high removal of bacteria. Pauwels and verstraete showed Enterococci were decreased below the detection limit in the MBR and indicator organisms such as fecal coliforms were decreased for $1.4 \mathrm{log}$ units in the convectional activated sludge system compared to a 3.6 log removal in the MBR [11].

\section{Waste Stabilization Ponds for the Treatment of Hospital Wastewater}

Waste treatment plant (Stablization pond) is still effective conventional biological/bio-chemical methods of sewage treatment in resource limited countries [18]. Facultative and maturation pond remove bacteria in various mechanism; Time (retention time as pathogen attenuation occurs over time), Temperature (faecal bacteria die off increases with temperature), High $\mathrm{pH}(>9)$, High light intensity plus high dissolved oxygen concentration [19].

Waste stabilization ponds can attain a 99.9\% faecal coliform reduction, and $100 \%$ removal of helminths, thus facilitating the recovery of the wastewater for agriculture in both restricted and unrestricted irrigation. The greatest pathogen reductions occur during the warm months during irrigation season. During these times, effluent standards that meet unrestricted irrigation are easily attained [20, 21]. However, different studies revealed that certain resistant bacteria pass the treatment plant. Study conducted in Southeast Queensland, Australia indicates certain strain of Staphylococcus aureus and Escherchia coli can survive the path of treatment process until the inlet,including chlorination [22]. The same study conducted in South Ethiopia showed microbial contamination of treated wastewater (total ciliform, faecal coliform and E. coli count) exceeds WHO standard levels; Shigella spp and Salmonella spp were also isolated from wastewater treatment plant outlet samples as shown in Figure 1 [3].

\section{Coliform and Multi-Drug Resistant Pathogens}

In hospital wastewater bacteria become resistant to a specific antibiotic by transfer of genes encoding for the resistance being transferred vertically to the bacteria's offspring or horizontally and become a source of acquired resistance against antibiotics with at least a factor of 2-10 times higher than domestic wastewater $[11,23]$. Previous studies indicated that hospital wastewater is a huge source of drug-resistant pathogens in the environment. For example Study conducted from European region showed hospital effluents had 1.5\% MDR (Multi Drug

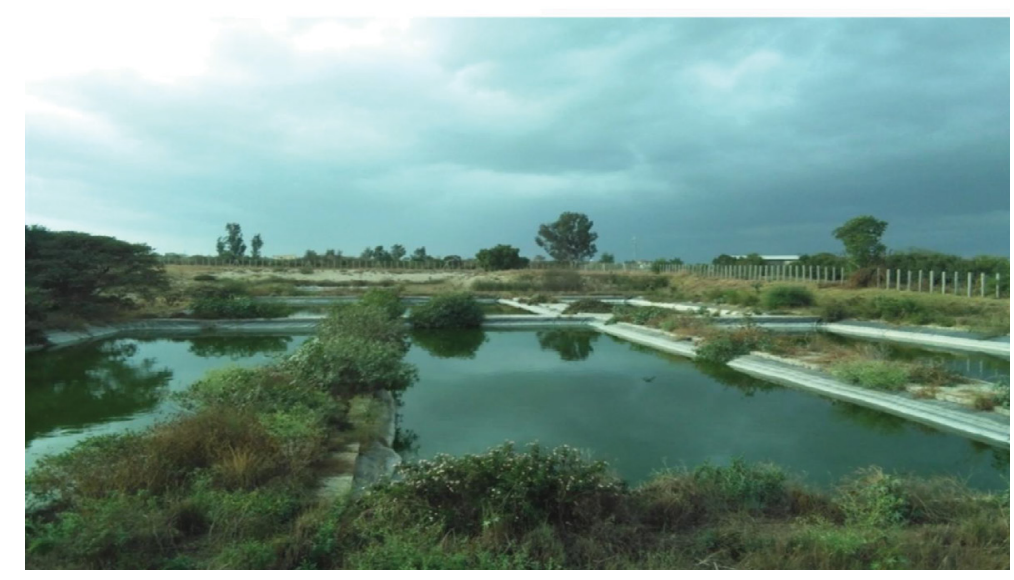

Figure 1. Improperly functioned treatment plant/oxidation ponds. (Source: Image from Ethiopia) 
Resistant) bacteria population [24]. In study conducted by Danish environmental protection agency, three multipleresistant strains (Acinetobacter johnsonii, Escherichia coli and Citrobacter freundii) isolated from treated hospital sewage were investigated for their ability to survive in natural waters and retain antibiotic resistance [25]. Study conducted in Belgium to compare the antimicrobial tolerance of oxytetracycline resistant heterotrophic bacteria from hospital sewage and freshwater fish farm water also showed similar findings [26]. Study conducted in India showed that presence of MDR bacteria in hospital samples ranged from $0.26 \%$ to $40 \%$, which is alarmingly high that could pose a serious problem for the community. Simultaneous resistance for ampicillin, amoxicillinclavulinic acid, piperacillin, second and third generation cephalosporin, cotrimoxazole, gentamycin, netilmycin and quinolones formed the common MDR pattern. The pattern was almost is almost the same for E. coli, Klebsiella, Enterobacter, Citrobacter and Pseudomonas and strongly suggests prevalence of similar R-plasmids $[27,28]$. Study conducted in Ethiopia, Gondar, also showed multiple drug resistance bacteria to the commonly used antibiotics is high in the hospital wastewater [29]. Previous studies indicated that coliform counts were also found to be high in hospital wastewater. Study conducted in Buenos Aires city hospital wastewater reveals bacterial counts ranged between $1 \times 10^{2} \mathrm{CFU}$ to $1 \times 10^{8} \mathrm{CFU} / 100 \mathrm{~mL}$ for coliforms; 1 to $4.8 \times 10^{5} \mathrm{CFU} / 100 \mathrm{~mL}$ for $E$. coli and 44 to $1.5 \times 10^{6}$ $\mathrm{CFU} / 100 \mathrm{~mL}$ for Enterococci. The proportion of enteric group varied from $58 \%$ to $75 \%$ of the total bacteria [7]. The sludge from hospital waste treatment facilities is also a potential source of infectious organisms. In a study by Tsai et al. [30], it was found that $1.4 \times 10^{6}, 3.6 \times 10^{5}$, $1.6 \times 10^{5}$ and $5.5 \times 10^{4} \mathrm{cfu} / \mathrm{g}$ (dry weight of sludge) for total coliforms, faecal coliforms, faecal streptococci and salmonella spp, respectively, Salmonella species were detected in $37 \%$ of sludge from hospital wastewaters. Hospital wastewater enterococci count of $10^{5} \mathrm{cfu}$ per $100 \mathrm{ml}$ was identified between countries. Most of the enterococci strains isolated belonged to the Enterococcus faecalis or Enterococcus faeciium together representing more than $60 \%$ of the entrococcal population [24].

\section{Contribution of Hospital Wastewater in Transferring Drug Resistance}

Microorganisms can settle in to a wide range of environmental, physical and chemical conditions, and become resistant to antibiotics used due to inadequate cleansing, incorrect product use or ineffective infection control practices [31]. Common resistance mechanisms among bacteria include; enzymatic inactivation, mutations in target sites, efflux pumps and intrinsic resistance [32-34].

Antibiotics used in hospitals for patient treatment are partially metabolized and excreted through feces and urine. Residual quantities of these products reach in hospital wastewaters making bacteria resistant to a wide range of biocides [15]. Antimicrobial excretion in combination with high microbial biomass and an abundance of nutrients makes wastewater a potential habitat for horizontal gene transfer and selection of antimicrobial resistant bacteria [35]. Specially, selection of resistant organisms can be expected in a hospital environment where drugs are used on a large scale [36]. This is the route by which resistance genes are introduced in natural bacterial ecosystems [37]. In such systems, non pathogenic bacteria could serve as a reservoir of resistance genes and platforms [38]. Antimicrobial resistance may spread in drinking and recreational water and become reservoir of clinical resistance genes, but also as a medium for spread and evolution of resistance genes and their vectors $[38,39]$. Opportunistic pathogens may become resistant upon acquiring resistant gene. Antibiotic resistance among environmental bacteria has led to consider as emerging pollutants [32], [40,41] and have a special property compared to other contaminants due to their ability to amplify, spread and persisting in the environment [41]. The presence of MDR in the environment is a major public health treat since it can infect humans and animals via contaminated food and drinking water, or directly from the environment [42]. Antibiotic resistance presents in bacteria which are not considered primary pathogens also, a threat to public health due to possibilities of transmittance of resistance to other microorganisms, especially human pathogens [43].

\section{Common Disease Transmitting through Hospital Wastewater}

Scientists believe there may be hundreds of disease causing organisms present in sewage and wastewater that have yet to be identified [45]. Therefore, health care wastes cause greater threat than from normal disease $[44,45]$. Several studies have evaluated the microbiological content of hospital and household waste and found that general hospital waste contains microorganisms with pathogenic potentials for humans comparable to household waste. Bacillus spp, Staphylococcus spp and Streptococcus species are bacteria frequently encountered in hospital wastewater, varying between $5 \%$ and 10\%, Escherichia coli, Pseudomonas aeruginosa has also been reported along with varying numbers of other nosocomial pathogens such as Klebsiella, Proteus and Enterobacter spp [46]. Most of these microorganisms have also been reported to be resistant to the commonly used antibiotics and as such have led to the outbreak of several diseases and infections [9]. Hospital wastewater can contain high concentrations of pathogens, especially in countries where diarrhoeal diseases and intestinal parasites are prevalent [47]. Therefore, if the wastewater is not properly treated, concentrated forms of infectious agents and antibiotic resistant microbes are shed into communities resulting in water borne diseases as shown in Figure 2 [48-50]. 


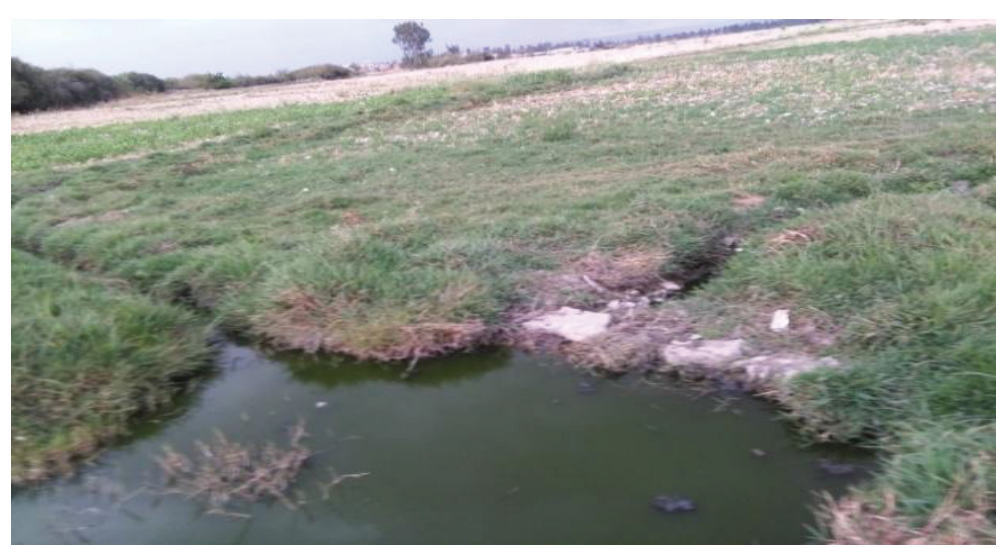

Figure 2. Hospital wastewater discharged to the open field. (Source: Image from Ethiopia)

\section{CONCLUSION}

The widespread emergence of drug-resistance among pathogens has become one of the most serious challenges worldwide. Hospital wastewater contains diverse group of disease causing organism and play a major role in the dissemination of drug resistant pathogens in the environment to become emerging pollutants through developing the property of amplifying, spreeding and persisting in the environment. These conditions become major public health problem especially in developing country since it can infect humans and animals via contaminated food and drinking water, or directly from the environment. Therefore, reduction of selective pressure by regulating the use of antibiotics is a key step to undermine the spread of resistance in hospital wastewater in order not to favored resistant strains in the environment. Proper manegment of hospital wastewater should be also practiced in every health institution inorder of reduce the problem.

\section{REFERENCE}

Abdel-Rouf N, Al-Homaidan AA, Ibraheem IBM (2012). Microalgae and wastewater treatment. Saudi. J. Biol. Sci. 19: 257-275.

Amine AEK (2013). Extended Spectrum Beta-Lactamase Producing Bacteria in Wastewater Alexandria. Egypt. Int. J. Bio. sci. Biochem. Bioinforma. 3: 605-608.

Fekadu S, Merid Y, Beyene H, Teshome W, Selassie S (2015). Assessment of antibiotic and disinfectant resistant bacteria in hospital wastewater, South Ethiopia. J. Infect. Dev.Ctries. 9: 149-156.

Beyene H, Redaie G (2011). Assessment of Waste Stabilization Ponds for the Treatment of Hospital Wastewater: The Case of Hawassa University Referral Hospital. World. Appl. Sci. J. 15: 142-150.

Stalder T, Barraud O, Jove T, Casellas M, Gaschet M,
Dagot C, Ploy MC (2014). Quantitative and qualitative impact of hospital effluent on dissemination of the integron pool. ISME J. 8: 768-777.

Keen PL, Patrick DM (2013). Tracking Change: a look at the ecological footprint of antibiotics and antimicrobial resistance. Antibiotics Review. 2: 191-205.

Nunez L, Moretton J (2007). Disinfectant-resistant bacteria in Buenos Aires city hospital wastewater. Braz. J. Microbiol. 38: 644-648.

Anitha J, Jayraaj IA (2012). Isolation and identification of bacteria from biomedical waste (BMW). Int J. Pharm. Sci. 4: 0975-1491.

Pandey A, Afsheen, Ara F, Kumar, Tiwari SK (2011). Isolation and characterization of multi drug resistance cultures from waste water. J. Pharm. Biomed. Sci. 13: 1-7.

Diwan V, Tamhankar AJ, Khandal RK, Shanta S, Aggarwal M, Marothi Y, Rama VL, Sundblad-Tonderski K, Stalsby-Lundborg C (2010). Antibiotics and antibioticresistant bacteria in waters associated with a hospital in Ujjain, India. BMC Public Health. 10: 414-422.

Pauwels B, Verstraete W (2006). The treatment of hospital wastewater. An appraisal. J. Water Health 4: 405-416.

Prayitno, Kusuma Z, Yanuwiadi B, Laksmono RW (2013). Study of Hospital Wastewater Characteristic in Malang City. Int. J. Eng Sci. 2: 13-16.

Rezaee A, Ansari M, Khavanin A, Sabzali A, Aryan MM (2005). Hospital Wastewater Treatment Using an Integrated Anaerobic Aerobic Fixed Film Bioreactor. Am. J. Environ. Sci. 1: 259-263.

Mahvi A, Rajabizadeh A, Fatehizadeh A, Yousefi N, Hosseini H, Ahmadian M (2009). Survey Wastewater Treatment Condition and Effluent Quality of Kerman Province Hospitals .World Appl. Sci. J. 7: 1521-1525. 
Ottosson JR, Jarnheimer PA, Stenstrm TA, Olsen B (2012). A longitudinal study of antimicrobial resistant faecal bacteria in sediments collected from a hospital wastewater system. Infect. Ecol. Epidemiol. 2: 7438-7445.

Arar A (1998). Background to treatment and use of sewage effluent. Treatment and Use of Sewage Effluent for Irrigation. Water Sci. Technol. 31: 313-319.

Danchaivijitr S, Wongchanapai W, Assanasen S, Jintanothaitavorn D (2005). Microbial and Heavy Metal Contamination of Treated Hospital Wastewater in Thailand. J. Med. Assoc. Thai. 88: 59-64.

Yan W (1999). Phosphorus and nitrogen transfers and runoff losses from rice field wetlands of Chaohu Lake. ChI. J. Appl. Ecol. 10: 312-316.

Ramadan H, Ponce VM (2008). Design and Performance of Waste Stabilization Ponds. J. Wat. Pollut. Cot. Fed. 76: $330-334$.

Mara DD, Pearson H (1998). Design Manual for Waste Stabilization Ponds in Mediterranean Countries, Leeds: Lagoon Technology International Ltd.

USEPA (2007). Stabilization Ponds, FWS Constructed Wetlands, and Other Aquatic System. Onsite Wastewater Treatment Systems Technology Fact Sheet 7, EPA 625/ R-00/008.

Katouli M, Thompson JM, Gundogdu A, Stratton HM (2012). Antibiotic resistant bacteria in hospital wastewaters and sewage treatment plant. Science forum and stakeholder engagement: Building linkages, collaboration and science quality. 225-229.

Kummerer K (2004). Resistance in the environment. J. Antimicrob. Chemother. 54: 311- 320.

Blanch AR, Caplin JL, IversenAKu HI, Manero AT, Vilanova X (2003). Comparison of enterococcal populations related to urban and hospital wastewater in various climatic and geographic European regions. J. Appl. Microbiol. 94: 994-1002.

Guardabassi L, Dalsgaard A (2002). Occurrence and fate of antibiotic, resistant bacteria in sewage. Danish Environmental Protection Agency.

Huys G, Gevers D, Temmerman R, Conckaert M, Denys R, Rhodes G, Pickup R, McGann P, Hiney M, Smith P, Swings J (2001). Comparison of the antimicrobial tolerance of oxytetracycline-resistant heterotrophic bacteria isolated from hospital sewage and freshwater fish farm water in Belgium. Syst. Appl. Microbiol. J. 24: 122-30.

Chitnis V, Chitnis S, Vaidya K, Ravikant S, Patil S, Chitnis DS (2004). Bacterial population changes in hospital effluent treatment plant in central India. Water Res. 38: 441-447.
Chitnis V, Chitnis D, Patil S, Kant R (2000). Hospital effluent: A source of multiple drug-resistant bacteria. Curr. Sci. 79: 989-991.

Moges F, Endris M, Belyhun Y, Worku W (2014). Isolation and characterization of multiple drug resistance bacterial pathogens from waste water in hospital and non-hospital environments, Gondar, Northwest Ethiopia. BMC Research Notes 7: 215-231.

Tsai CT Lai JS, Lim ST (1998). Quantification of pathogenic microorganisms in the Sludge from treated hospital wastewater. J. Appl. microbiol. 85: 171-176.

Wyasu G, Okereke NZJ (2012). The influence of hospital wastewater and food samples grown within Ahmadu Bello University teaching hospital, Zaria-Nigeria on its receiving environment. Adv. Appl. Sci. Res. 3: 16861690.

Wright GD (2010). Antibiotic resistance in the environment: a link to the clinic? Curr. Opin. Microbiol. 13: 589-594.

Wright GD (2007). The antibiotic resistome: the nexus of chemical genetic diversity. Nat. Rev. Microbiol. 5: 175-186.

Allen HK, Donato J, Wang HH, Cloud-hansen KA, Davies J, Handelsman J (2010) Call of the wild: antibiotic resistance genes in natural environments. Nat. Rev. Microbiol. 8: 251-259.

Periasamy D, Sundaram A (2013). A novel approach for pathogen reduction in wastewater treatment. J. Environ. Health. Sci. Eng. 11:12-21.

Pardo T, Pereira WC, Silva DM, Seki LM, Carvalho AP, Asensi MD (2007). Detection of extended-spectrum beta-lactamase-producing Klebsiella pneumoniae in effluents and sludge of a hospital sewage treatment plant. Lett. Appl. Microbiol. 46:136-341.

SaiGopal DVR, Usha K (2013). Occurrence of various beta-lactamase producing gram negative bacilli in the hospital effluent. Asian. J. Pharm. Clin. Res. 6: 42-46.

Hilary-Kay Y (1993). Antimicrobial resistance spread in aquatic environments. J. Antimicrob. Chemother. 31: 627-635.

Ahmed M, Khan AU, Wahid A, Ali But Z, Farhan M, Ahmad F (2012). Role of hospital effluents in the contribution of antibiotics and antibiotic resistant bacteria to the aquatic environment. Pak. J. Nutr. 11: 1177-1182.

Kummerer K (2009). Antibiotics in the aquatic environment. A review- Part I. Chemosphere 75: 417-434.

Pruden A, Pei R, Storteboom H, Carlson KH (2006). Antibiotic Resistance Genes as Emerging Contaminants: Studies in Northern Colorado. Environ. Sci. Technol. 40: 7745-7750.

Saif Al-Bahry IY, Mahmoud IY, Paulson JR, Al- 
Musharafi SK (2014). Survival and growth of antibiotic resistant bacteria in treated wastewater and water distribution system and their implication inhuman health: A review: Int. Arab. J. Antmcrob. Agent. 4: 1.

Van der Kooij D, Van Lieverloo JHM, SchellartJ, Hiemstra P (1999). Maintaining quality without a disinfectant residual. J. Amer. Water-Works. Assoc. 91: 55-64.

Omar Faruk SM, Masudul Azad CAM, Nayeem UK (2014). Isolation of Cefixime Resistant Salmonella from Hospitals waste and Profiling Multi-drug Resistance Pattern of the Selected isolates. Int. Res. J. Biological. Sci. 3: 86-92.

World Health Organization (2012): Public Health and Environment. Overview of Wastes from Health Care Activities.UNEP IETC Osaka, Japan.

Oyeleke SB, Istifanus N, Manga SB (2008). The effects of hospital solid waste on the receiving environment. Int. J. Integr. Biol. 3: 191-95.
World Health Organization (2006). Wastewater management. Pathogens found in untreated wastewater. A UN-water analytical brief: Adapted from WHO.

Khan Md. Ashfaq A, Pijush S, Majharul IM, Kant OR, Chandra BG (2013). Screening of antibiotic resistant gram negative bacteria and plasmid profiling of multi-drug resistant isolates present in sewage associated with health care centers. Int. J. Med. Res. Health. Sci. 2: 923-930.

Bush K, Courvalin P, Dantas G, Davies J, Eisenstein B, Huovinen P, Jacoby GA, Kishony R, Kreiswirth BN, Kutter E, Lerner SA, Levy S, Lewis K, Lomovskaya O, Miller JH, Mobashery S, Piddock LJ, Projan S, Thomas CM, Tomasz A, Tulkens PM, Walsh TR, Watson JD, Witkowski J, Witte W, Wright G, Yeh P, Zgurskaya HI. (2011) Tackling antibiotic resistance. Nat. Rev. Microbiol. 9: 894-896.

Asfaw T, Negash L, Kahsay A, Weldu Y (2017). Antibiotic Resistant Bacteria from Treated and Untreated Hospital Wastewater at Ayder Referral Hospital, Mekelle, North Ethiopia. Advances in Microbiology. 7: 871-886. 